\title{
Family experience of living with children and adolescents with bladder and bowel dysfunction
}

\author{
Experiência da família no convívio com a disfunção vesical e intestinal de crianças e adolescentes \\ Experiencia de la familia en conversación con disfunción vesical e intestinal en niños y adolescentes
}

Universidade de Brasília. Brasília, Distrito Federal, Brazil.

How to cite this article:

Rodrigues NS, Martins G, Silveira AO. Family experience of living with children and adolescents with bladder and bowel dysfunction. Rev Bras Enferm. 2020;73(Suppl 4):e20190805. doi: http://dx.doi.org/10.1590/0034-7167-2019-0805

Corresponding author:

Nayara dos Santos Rodrigues E-mail: nsrodrigues94@gmail.com

EDITOR IN CHIEF: Antonio José de Almeida Filho ASSOCIATE EDITOR: Fátima Helena Espírito Santo

Submission: $01-24-2020$

Approval: 05-18-2020

\begin{abstract}
Objective: to understand the experience of families of living with children and adolescents with bladder and bowel dysfunction. Methods: a qualitative phenomenological interpretive research carried out through an in-depth open interview with parents of children and adolescents linked to Advanced Practice Nursing clinic in pediatric urology. Results: the following representative categories of the families' experiences emerged: Knowledge and learning: building family knowledge; Living with the children's BBD: symbolic representations; Management and adaptation to the children's BBD: reorganizing family life. Final considerations: the experience of families related to positive and negative meanings, presence or absence of previous experiences, information gaps, learning process and access to specialized professional follow-up. Follow-up by nurses is important in pediatric urology care for the learning and consolidation of specific knowledge about bladder and bowel dysfunction. Descriptors: Family; Child; Adolescent; Pediatric Nursing; Advanced Practice Nursing.
\end{abstract}

\section{RESUMO}

Objetivo: compreender a experiência da família no convívio com a disfunção vesical e intestinal de crianças e adolescentes. Métodos: pesquisa qualitativa fenomenológica interpretativa realizada por meio de entrevista aberta em profundidade com pais de crianças e adolescentes vinculadas ao ambulatório de Prática Avançada de Enfermagem em uropediatria. Resultados: emergiram as seguintes categorias representativas das experiências das famílias: Conhecimentos e aprendizados: construindo o saber familiar; Convivendo com a disfunção vesical e intestinal da criança: representações simbólicas; Manejo e adaptação à disfunção vesical e intestinal da criança: reorganizando a vida familiar. Considerações finais: a experiência da família relaciona-se a significados positivos e negativos, à presença ou ausência de vivências prévias, lacunas de informações, ao processo de aprendizagem e acesso ao acompanhamento profissional especializado. Destaca-se a importância do acompanhamento pelo enfermeiro no contexto do cuidado em uropediatria para a aprendizagem e consolidação do conhecimento específico sobre a disfunção vesical e intestinal.

Descritores: Família; Criança; Adolescente; Enfermagem Pediátrica; Prática Avançada de Enfermagem.

\section{RESUMEN}

Objetivo: comprender la experiencia familiar de vivir con disfunción vesical e intestinal en niños y adolescentes. Métodos: investigación fenomenológica interpretativa cualitativa, realizada a través de una entrevista abierta en profundidad con padres de niños y adolescentes vinculados a la clínica ambulatoria de práctica avanzada de enfermería en uropediatría Resultados: surgieron las siguientes categorías representativas de las experiencias de las familias: Conocimiento y aprendizaje: construcción del conocimiento familiar; Vivir con la vejiga y la disfunción intestinal del niño: representaciones simbólicas; Manejo y adaptación a la vejiga y disfunción intestinal del niño: reorganizando la vida familiar. Consideraciones finales: la experiencia de la familia está relacionada con significados positivos y negativos, la presencia o ausencia de experiencias previas, lagunas de información, el proceso de aprendizaje y el acceso a monitoreo profesional especializado. Se destaca la importancia del monitoreo por parte de las enfermeras en el contexto de la atención uropediatrica para el aprendizaje y la consolidación del conocimiento específico sobre la disfunción intestinal y vesical. Descriptores: Familia; Niño; Adolescente; Enfermería Pediátrica; Enfermería de Práctica Avanzada 


\section{INTRODUCTION}

Bladder and bowel dysfunction (BBD) is proposed by the International Society for Continence of Children (ISCC), and is a broad term that encompasses the concomitant presence of symptoms of lower urinary tract dysfunction (LUTD) and bowel dysfunction ${ }^{(1)}$.

LUTD can be characterized by symptoms according to the relationship it has with the bladder storage phase (change in urinary frequency, incontinence, urgency, and nocturia); bladder emptying phase (hesitation, effort, weak or intermittent jet, and dysuria); or even with other symptoms (containment maneuvers, feeling of incomplete emptying, urinary retention, post-micturition dribbling, and pressure jet) ${ }^{(1)}$. While the presence of symptoms of bowel dysfunction is related to functional constipation (FC). The function of the digestive system is preserved, however hard stools or difficulties in elimination are referred to ${ }^{(2)}$. FC is often diagnosed in the presence of its complications, such as fecal incontinence, recurrent abdominal pain, enuresis or even urinary tract infection ${ }^{(3)}$.

For the clinical diagnosis of LUTD in children, it is adopted as a criterion to have the age of 5 years or older, and for FC, the minimum age of 4 years, moments in which urinary and fecal continence of children acquired after going diaper-free is expected ${ }^{(1)}$.

The instruments used for the clinical diagnosis of BBD are the Dysfunctional Voiding Scoring System (DVSS), Rome IV and the Bristol Stool Form Scale (BSFS). The DVSS aims to measure the severity of urinary symptoms through ten questions with scores from zero to three, with the final score ranging from zero to thirty points, according to the occurrence of symptoms in the last thirty days ${ }^{(4)}$. This instrument was translated into Brazilian Portuguese and validated in a study developed by Calado et al $(2010)^{(5)}$. Rome IV is the standardization for FC diagnostic purposes, which is widely accepted and used in clinical practice ${ }^{(6)}$. The BSFS is an instrument that aims to characterize fecal eliminations in a descriptive manner, characterizing them in terms of their shape and consistency ${ }^{(7)}$. This tool helps children and their parents to describe the type of stools based on a visual scale and descriptions associated with appearance. Its translation and validation into Brazilian Portuguese was performed by Martinez and Azevedo (2012)(7).

Nursing literature shows high prevalence of LUTD in children in the school age group, especially in girls with greater economic vulnerability, affecting family dynamics, and may cause low selfesteem, anxiety, depression, insecurity, decreased social life and increased stress in children and their families ${ }^{(8-11)}$. LUTD is also associated with complications such as recurrent urinary tract infection, vesico-ureteral reflux and, in the most severe cases, injuries and loss of kidney function ${ }^{(6)}$.

The family's experience in living with the symptoms of BBD is sometimes guided by frustration, shame, anxiety, guilt, as well as impairments in self-esteem, self-confidence and quality of life of children and their families, and they must develop coping and adaptation strategies ${ }^{(12-14)}$. This factor reinforces the importance of promoting healthy elimination habits in order to avoid complications and the need to access the experiences of families through appropriate follow-up that is sensitive to the social and emotional factors involved.

In this respect, the role of nurses in BBD management in the pediatric context stands out, which is still incipient in the Brazilian setting. We highlight a nursing service in the Federal District that uses international references such as the Advanced Practice Nursing (APN) model in uropediatrics, with a view to promoting pediatric continence ${ }^{(15)}$. In this service, the nursing staff's work process is based on shared decision and linked to a family-centered care model for care therapeutic planning provided to children with chronic urinary and bowel diseases symptoms. Nurses are the professionals referred to carry out this function ${ }^{(16)}$.

Therefore, the following question emerged: what are the experiences of families of children and adolescents affected by symptoms of BBD?

\section{OBJECTIVE}

To understand the experience of families of living with children and adolescents in outpatient follow-up with BBD.

\section{METHODS}

\section{Ethical aspects}

The Ethics Committee of Universidade de Brasília approved this research. All participants signed the Informed Consent Form (ICF). To maintain confidentiality, the participating families were identified in the study with the letter $E$, followed by the number representing the order of the interview (E1 to E11).

\section{Theoretical-methodological framework}

To carry out this study, interpretive phenomenology was used, in the perspective of Patrícia Benner as a theoretical and methodological framework. Interpretive phenomenology aims to understand everyday skills, practices and experiences, finding examples or paradigmatic cases that represent instances of the significant pattern and portraying the person in the situation, preserving the meanings and contexts of the life world ${ }^{(17)}$. The phenomenological theory in Benner's perspective proposes to understand human experiences beyond the meanings of experiences for the research subjects, thus placing human beings in a central position in the study ${ }^{(18)}$.

\section{Type of study}

This is a qualitative, interpretative, and cross-sectional research.

\section{Study setting}

The study was carried out at an APN outpatient clinic in uropediatrics of a teaching hospital in center-western Brazil. The APN outpatient clinic in uropediatrics is an Extension Project of Continuous Action in the field of nursing in pediatric urology and aims to provide specialized nursing care for children with urinary and bowel symptoms ${ }^{(15)}$.

\section{Data source}

The study participants were selected according to the intentional sampling technique to capture experience diversity and strengthen data quality ${ }^{(17)}$. Thus, families of children and 
adolescents who met the following inclusion and exclusion criteria participated in the study, based on the previous evaluation of patients' medical records.

Family (parents or primary caregivers) of children and/or adolescents aged 5 to 18 years of both sexes diagnosed with $\mathrm{BBD}$, followed up at the service during data collection have been included in the study. Children or adolescents with neurological or cognitive disorders, genitourinary and/or bowel tract malformations have been excluded from the study.

It is important to mention that nine of the eleven interviews were conducted with families of children aged up to twelve years. Therefore, aiming at uniformity in the description of results and discussion, the use of the term "child" was standardized for all interviews.

\section{Data collection and organization}

Data collection took place from October 2018 to January 2019, starting with the identification of diagnostic criteria for BBD, using DVSS, ROME IV, and EFB, based on medical record analysis. After the identification of potential research participants, invitations were made to integrate the study with explanations and ICF thorough reading. Considering the agreement, data collection began, which consisted of the application of a socio-demographic characterization questionnaire (elaborated by the researchers); construction of family genogram and eco-map; and an in-depth open interview conducted by the main researcher.

The interviews were conducted in a private room, audiorecorded, with an average duration of 30 minutes and had the guiding question "How is it like to live with the condition of your child/teenager diagnosed with BBD?"Intermediate questions were incorporated considering the need to deepen the understanding of content such as meanings and perceptions, in addition to family, social relationships and activities of daily living.

\section{Data analysis}

Data analysis followed the methodological assumptions of phenomenological interpretative research in Benner's perspective, dividing into transcription, coding, thematic analysis and search for paradigmatic and exemplary cases ${ }^{(18)}$. Therefore, the researchers' previous knowledge becomes a constituent part of the interpretative process, consolidating study conduction ${ }^{(18)}$.

All interviews were transcribed by the main researcher and analyzed individually to reach the units of meaning and together the coding stage was carried out. This procedure took place in a parallel manner, so that on each new day of interviews, the interviews conducted previously had already been transcribed and coded. As a consecutive step, there was a categorization in which an exhaustive reading of all interviews was carried out in search of similar codes for grouping collaterally to the data collection process.

Code agglomeration aimed to provide a better understanding and delimitation of the units of meaning, generating at the end of thematization and listing of the exemplary and the paradigmatic cases. It is worth mentioning that this whole process took place in an integrated manner, since researchers must always remain open to new emerging interpretations, given the transitory and contextual nature of human activities ${ }^{(17)}$.
We sought to meet the Consolidated Criteria for Reporting a Qualitative Research (COREQ) recommendations for the writing of this study ${ }^{(19)}$.

\section{RESULTS}

The study had the total participation of eleven families. Twelve were invited, but one refused to participate. Concerning participant characterization, most parents were married (7); had a family income of one to two minimum wages (6); had two children (6); had a young child with BBD (8); had a child with BBD with an average age of 9 years; had children with BBD attending public school (8); and had a child with BBD with agitated/hyperactive temperament (6).

At first, the study aimed to capture knowledge about BBD from the family's perspective. However, during the interviews, it was found that the participants explained subjects not only related to their knowledge. Thus, it was noted that the understanding of knowledge is related to a larger dimension, the experience with the studied phenomenon.

During the data analysis process, the following categories that emerged from the experience of families of children with BBD emerged: Knowledge and learning: building family knowledge; Living with the children's BBD: symbolic representations; Management and adaptation to the child's BBD: reorganizing family life.

\section{Knowledge and learning: building family knowledge}

It is understood that the process of dealing with a disease involves much more than its clinical implications for the individual's health and care demands. In this context, in order to understand the construction of family knowledge, it is necessary to capture previous or acquired knowledge during the experience. The family's trajectory that had previous experiences with BBD in their eldest son stands out in the narratives.

As the older one already has this nervous bladder problem, it was easier, as he was already followed up, and I had guidance, so it was all easier. (E2)

On the other hand, getting used to the presence of the symptom can assign a meaning of normalization so that it is no longer seen as a problem, but as a common situation.

Most of the family, family members, have already peed on the bed [...] but it was not so much like her. There was my brother, who was about ten years old, eleven years old. My husband said he also peed on the bed. For my family, it's normal. (E6)

It is noteworthy that the initial identification of BBD by the family that has previous experiences is different from families that have not had such experiences. For this second group of families to deal with the unknown, it often implies overestimated meanings of the symptoms.

Ithought itwas a bowel malformation, for his bladder, the bladder. (E8)

[...] I thought it was a problem, that she had a low bladder, so I was already terrified and she also [...] of being something more serious [...] we found out it wasn't what we were thinking. (E9) 
Ah, I thought she could have a more serious problem too, because I think this business of holding urine could bring something more serious. (E10)

In the speeches, the important role of specialized professional accompaniment for the learning and consolidation of specific knowledge about BBD is unveiled. In addition, habitual care must be modified and introduced into the lives of children and their families.

There is a lot that I learned at the last consultation, three months ago, that we already put into practice and improved. (E1)

Before, we had no worries, but now we are having, you know, you are getting more information. (E8)

After llearned about uropediatrics, I thought this treatment she is doing better now, because she has improved a lot. (E6)

It is understood that many families from the knowledge about the child's BBD and with the experience of the symptom refer to an appropriate management, with the adaptation taking place smoothly.

For me, it's normal, I got used to it. I've gotten used to it and everyone at home, for us it's easy. [...] we learned to live with that. It was very easy; it was very fast for us to live and learn. (E5)

[...] but there, it's quiet now. (E6)

[...] ah, now it's ok, now we know how to deal with. (E8)

However, some families still demonstrated some difficulty related to the presence of information gaps in the child's BBD. Thus, presenting basic questions such as what does BBD mean, what is the treatment, if it has a cure and what are the results to be achieved.

[...] to know what the result will be. To find out what's going on, why this happened. We are also curious to know why this happens. (E4)

[...] is bladder and bowel dysfunction treated? [...] I asked if there was a cure, if there is treatment, how it works. (E11)

\section{Living with the children's bladder and bowel dysfunction: symbolic representations}

To understand knowledge, it is necessary to capture the symbolic representations of families. In this way, many families report not associating BBD with a disease, relating it to emotional and behavioral issues.

[...] of the psychological treatment, it is neither physical disease nor illness at all. [...] when he can control his desires, he can take it normally. (E2)

Yeah, I don't see it as a disease, I see that we just have to police ourselves more in this area. (E3)

This, for me, is not a disease, for me it's kind of a problem [...] I don't think because for me, disease is other things, it is more serious things. (E5)

Idon't see it as a disease. (E6)
Thus, when attributing to BBD an emotional causality, some families treat the symptom in a secondary way in which the perception of its impacts on the children's and family's life is not identified.

It had no impact for him. (E5)

It had no impact on her life, it is more peaceful [...]. (E8)

It does not affect the routine [...]. (E9)

No, I don't think it affected anything in the family's life. (E11)

On the other hand, some families pointed out that BBD had a greater impact on the child's own life, identifying the impairment in their health.

Only affect his health, but for us he didn't marry anything. (E2)

This affected his life more [...] in health and emotion [...] because if he doesn't do it, he gets anxious. (E11)

Feelings are part of the experience of having a child with BBD, relating it to the way it identifies and deals with the problem. It is understood from the narratives that most families referred to negative meanings that result in anguish, fear, anxiety, sadness, discouragement, impotence, and frustration in different stages of the experience with BBD.

It was bad to know, I didn't like it. [...] I would like her to stop wetting the bed, it sucks. (E4)

It was scary, right, because we didn't expect it. (E5)

I was surprised, I was surprised by this and I was scared too. (E9)

We are sad to see that he has these difficulties in making or arresting the pee. And having difficulty going to the bathroom, we are worried, we know that it is not good [...] we are frustrated, we want to help and often cannot, we do not see results. (E11)

On the other hand, the association of positive meanings with the family's perception of improvement in the child's condition was identified in the narratives, resulting in feelings of adequacy, overcoming, relief, and tranquility.

When the child gets better, the concern also decreases. (E2)

[...] after she explained what it was like, what she had to do in order to be able to return to normal, I got calmer. (E9)

[Father] I no longer see his mother suffering as she did before. [Mother] Yes, now I can see how to overcome it. (E11)

\section{Management and adaptation to the children's bladder and bowel dysfunction: reorganizing family life}

BBD resolution implies modification of usual care so that the family performs a reorganization in different aspects of daily life. With regard to food, some families reported the perception of 
adaptation or improvement in the acceptance of dietary changes and the adequate intake of fluids, especially water intake.

\author{
I always had this concern of looking for some fruit, something to \\ loosen her bowel. (E1) \\ To be demanding [...] to drink water. (E3) \\ [...] she changed some habits, now she has more habit of drinking \\ water, her bottle is separate for her to drink water. (E6)
}

She started with food to see if the disease improves [...] my husband started to buy more fruits [...] he started to eat more fruits, and juices and water. (E7)

Care with food [...]. (E11)

Reprogramming the use of the bathroom is also provided, with the reinforcement of regular visits, encouragement and monitoring of the family so that the child uses the bathroom and makes its eliminations with the appropriate regularity, involving different family members in this task.

\section{[...] demanding that she go to pee at the right times. (E3)}

We try as much as possible to be there charging her, asking if she has already been to the bathroom. (E7)

It is this incentive that she always has to do to go to pee, to always remember her. (E10)

You have to send her to the bathroom. (E11)

Due to BBD, some families reported difficulties in leaving the house with the child and adopting the restriction to the domestic environment and, therefore, the limitation of social interaction as an adaptive behavior.

I try to leave and come back quickly because she can't poop ... other than at home, so I always schedule to go out one day and come back at the most the next day. (E1)

If I went somewhere, I had to stop in the middle of the street to evacuate, because she can't hold it. (E2)

I usually stay at home; I don't like to go to other people's houses to spend a long time with her there. (E3)

\section{Paradigmatic cases}

Two paradigmatic cases were identified related to the different experiences with the child's BBD in the management and experience of symptoms.

In the first case, it is understood that the family's prior knowledge of associating the symptom's manifestation with the will of children implied exhaustive demands by the mother and use of physical punishments.

Because it's boring, right[laughs]. For me, it's boring. Her aunts, her grandmother, even feel sorry for her, saying "poor girl, don't fight with her", she asks me not to fight. [...] right at the beginning I used to do this, but now I stopped. I saw it's not because she wants to. [...] she says it herself, not because I want to, but only that her father already, her father sometimes says that she has to stop it ... she thinks it is because the girl wants it, then he already it is more different from me. (E4)

In this narrative, negative feelings of maternal frustration were expressed in the face of the difficulty of controlling the symptom's manifestation, also reinforcing the doubts and information gaps regarding the child's BBD. The questions cross the field of acceptance of the occurrence of the symptom, as well as the desire for a definitive resolution.

Yeah, for me it's a little difficult, because I have to wake up at night, at dawn, for her to go to the bathroom. And, even more that she is turning 12 and it gets boring. [...] for me, it's not normal. Something's wrong, because it's not normal. [...] to know what the result will be? To know what's going on? Why did that happen? We are also curious to know why, why it happens. (E4)

In the second case, it is understood that the lack of prior knowledge about BBD in addition to the lack of ability of health professionals to adequately and sufficiently inform children and family, preparing them for the procedure, generated traumatic experiences. Having to apply a medication to treat constipation caused great suffering in the family.

He had a headache once, and he had nothing, nothing that the tests could detect. The doctors discovered it was constipation. We even applied a medicine so he could evacuate. For us, that was very boring. [...] unpleasant to see my wife cry, because in this case, like you are going to take a child and apply a suppository to a child. [...] it hurt us a lot. (E11)

And despite this, this family has developed a good adaptation to the management of the symptom, adopting a modified care, treating with sensitivity the demands presented by the child and referring positive feelings from the perception of the evolution.

We take it well, we can't focus like that, otherwise you can pass the anxiety to him, you can pass the worry that he sees us 'oh you have to do it all the time' you can pass this anxiety from us to him, for not seeing the evolution of his picture [...] he's evolving, right, of having to say 'oh today you didn't do it right', having to keep an eye on him. [...] but the evolution was great. (E11)

\section{DISCUSSION}

The understanding obtained in this study, through the interpretative phenomenological method, made it possible to elucidate the family experience of children with BBD, their conceptions, actions and influences on symptom adaptation and management.

Families were made aware of the perception of BBD symptoms with the presence or absence of previous experiences. Furthermore, it should be noted that a family well informed about the disease and empowered with the necessary care develops autonomy in the organization of their life ${ }^{(10)}$. Thus, the first step in the management of BBD is the demystification and education of 
children and their parents, aiming to reduce anxiety and possible accusations, increasing the chances of effective involvement in therapeutic management ${ }^{(6)}$.

When reporting in the narratives the relevance of professional monitoring for learning and consolidating knowledge, the importance of pediatric nursing care that is centered on children and their family is emphasized when employing the principles of shared information and family empowerment ${ }^{(20)}$.

In this sense, there are some weaknesses in the families' knowledge about BBD with the lack of information on the subject. Thus, two families brought basic doubts about BBD in their narratives through questions about what BBD means, why it occurs, what is its treatment, if it has a cure and what results are to be achieved.

Similar results are found in the pediatric context of different chronic diseases, in which the family needs information about the disease, specifically covering symptoms, home care, treatment and prognosis ${ }^{(21-22)}$. A study conducted by Cederblad et al (2014) $)^{(12)}$ highlights the need for information from families about the cause, recurrence and age for starting enuresis treatment in children.

With the narratives, it was possible to understand that families attribute different meanings to BBD. Many families reported not considering BBD as a disease, attributing the symptom's manifestation to psychological and behavioral issues. This understanding is in line with what Perez (2014) discusses ${ }^{(23)}$. Many people believe that psychological problems cause continence problems, when, in fact, most children have physical problems that lead to psychological impairment. These conceptions can be highlighted that incontinence is a chronic disability surrounded by stigmas, influencing the meaning attributed to $\mathrm{it}^{(24)}$.

In some narratives, the idea of blaming the children or understanding the manifestation of the symptom conditioned to their will was observed, resulting in moral repression and/or the use of physical punishment. Caregivers frequently submit children to embarrassing situations and/or fight and beat with the aim of punishment ${ }^{(25)}$. It should be noted that one of the most relevant nursing interventions for managing BBD should begin with the understanding that children are not to blame for the symptom ${ }^{(26)}$.

Another aspect also assessed at this point concerns the fact that some families deny impacts caused by BBD on the family's life, referring only to the child's own life. However, as the daily experience with BBD was deepened, changes in eating and elimination habits were reported, with greater parental attention and changes in the family routine. Related to this, the families brought reports about changing habits based on the knowledge acquired about healthier eating, adequate daily fluid intake, especially with the stimulus to drink water and healthy elimination habits, with the voiding reprogramming and positioning correct to use the toilet, with the use of seat reducer and footrest. This practice is based on the principles of urotherapy, in which, primarily, the modification of behavior related to the habits of elimination, eating and healthier lifestyles is adopted, in order to contribute to the relief or resolution of BBD symptoms ${ }^{(1.26)}$.

Also noteworthy are the experiences reported by three of the eleven interviewed families, of limited social interaction represented by the restriction to the domestic environment due to children having difficulties with the increased frequency of trips to the bathroom or due to the difficulty of carrying out eliminations in unfamiliar environments. Therefore, the fact that families have developed the strategy of limiting their social interaction as a way of adapting to everyday reality due to the symptom manifestation is similar to the findings of Cederblad et al (2014) ${ }^{(12)}$, when referring that families of children with bedwetting need to develop coping strategies and adaptation to daily life due to the symptom manifestation. It is also evident that the quality of life of children and their families is compromised due to the presence of constipation or fecal incontinence ${ }^{(13)}$.

When comparing the two paradigmatic cases, it is highlighted that both families experience delicate experiences with the manifestation of BBD symptoms and their complications. However, in the first case, the family has not completed the problem adaptation cycle in which the family's internal behaviors are contradictory and questions in the field of acceptance of the problem are made. In the second case, the family shows that, by going through the recognition of the symptom through a traumatic experience, it was able to adapt to the care demands for the management of $\mathrm{BBD}$, referring to positive feelings with the evolution. Therefore, it is questioned whether the fact that the second family is able to identify improvement in the symptom manifestation can influence their actions and posture before the problem, a factor that was not mentioned in the first family.

In view of these findings, it is emphasized that the early identification of BBD is important to avoid an important social and medical burden so that the persistence of the symptom can negatively influence the family and school relationship networks of the child, subjecting them to embarrassing situations and punishments ${ }^{(25-26)}$. Therefore, the importance of promoting healthy elimination habits is reinforced to avoid complications, in addition to the appreciation for adequate monitoring that is sensitive to the social and emotional factors involved.

In this perspective, the nurse's performance must be guided by a constant practice of valuing interpersonal relationships and the experiences of the children and their family, aiming to meet the needs presented with educational and psycho-emotional support strategies ${ }^{(27-29)}$. The presence of nurses in urological services or for the management of urinary and fecal continence is recognized in the assessment and initial treatment. There is the potential to reduce queues and the number of patients who need a medical evaluation, in addition to the high levels of satisfaction reported by patients ${ }^{(30-32)}$.

The work of nurses specializing in uropediatrics requires broad affinity with the information gaps presented by families as well as the knowledge they have, with communication techniques that are effective with children and their family ${ }^{(15)}$. Therefore, the APN outpatient clinic in uropediatrics, by adopting child-centered care and their family, enhances the chances of nurses acting in accordance with the experiences that families have about BBD. For instance, attribution of positive or negative meanings, influences on parenting and family organization styles, as well as the presence or absence of prior knowledge related to the management, acceptance and adherence to the proposed treatment.

\section{Study limitations}

Among the limitations of this study, the BBD nomenclature was established only four years ago by ICCS(1). Its use in research 
in the field is still incipient, for this reason the discussion presented here was mostly based on research results addressing the old LUTD nomenclature or even addressing isolated urinary or bowel symptoms.

Another weakness is related to the fact that the experiences included in this study are limited to families that were linked to a specialized nursing service. Therefore, it is questioned whether families that are not linked to specialized services have the same experiences in living with BBD.

\section{Contributions to nursing}

Families have their own concepts, habits and practices that influence management and needs to be accessed by nursing professionals who work in pediatric urology care to achieve family engagement as well as the resolution of symptoms. Thus, the role of these professionals stands out when carrying out urotherapy interventions such as demystification, stigma reduction, changes in elimination habits and achievement of positive health outcomes associated with not shaming the child, improved quality of life and reduced impact of BBD symptoms on the lives of children and their families.

\section{FINAL CONSIDERATIONS}

The results made it possible to understand the concerns, meanings, experiential learning, skills and practical behavior of families in their daily contact with the children's BBD. Furthermore, many families report not associating BBD with a disease, attributing it to emotional and behavioral issues. The meanings associated with the experience of living with children with BBD stand out, with negative ones resulting in feelings such as anguish, fear, anxiety, sadness, discouragement, impotence and frustration in different stages of living with BBD. The positive meanings are related to the family's perception of improvement in the child's condition, resulting in feelings of adequacy, overcoming, relief and tranquility.

The interviewed families demonstrated that their conceptions and actions regarding children's BBD are based on their previous experiences or even on their absence, information gaps and the learning process. These factors can facilitate management and adaptation to symptoms. When it comes to the naturalization of children's symptom or blame, the recognition of its abnormality is difficult, which may result in physical punishments and difficulty in adhering to treatment.

Understanding the experience that families have with BBD is an essential factor for the APN nurse to propose interventions that are sensitive to the world of life. Therefore, the importance of the APN outpatient clinic in pediatric urology is noted for its sensitive performance to the experiences that families have about BBD, such as the attribution of positive or negative meanings, the influences on parenting and family organization styles, as well as the presence or absence of prior knowledge related to the management, acceptance and adherence to the proposed treatment.

Considering the results, the study shows the importance of monitoring by a specialized nurse to learn and consolidate specific knowledge about BBD, who is able to influence positive outcomes with actions related to BBD symptoms and their impacts on the lives of children and their families.

\section{FUNDING}

This study received the financial support for publication provided by the University of Brasília. Financing notice DPI | DPG - UnB Nº2/2020.

\section{REFERENCES}

1. Austin PF, Bauer SB, Bower W, Chase J, Franco I, Hoebeke P, et al. The standardization of terminology of lower urinary tract function in children and adolescents: update report from the Standardization Committee of the International Children's Continence Society. Neurourol. Urodyn. 2016;35(4):471-81. doi: 10.1002/nau.22751

2. Galvão-Alves J. Constipação intestinal. J. bras. med. [Internet]. 2013 [cited 2019 Sep 14];101 (2). Available from: http://files.bvs.br/ upload/S/0047-2077/2013/v101n2/a3987.pdf

3. Hyams JS, Di Lorenzo C, Saps M, Shulman RJ, Staiano A, van Tilburg M. Childhood functional gastrointestinal disorders: child/adolescent. Gastroenterology. 2016. 150(6):1456-68. doi: 10.1053/j.gastro.2016.02.015

4. Farhat W, Bägli DJ, Capolicchio G, O'Reilly S, Merguerian PA, Khoury A, et al. The dysfunctional voiding scoring system: quantitative standardization of dysfunctional voiding symptoms in children. J Urol. 2000;164(3 Pt 2):1011-5. doi: 10.1097/00005392-200009020-00023

5. Calado AA, Araujo EM, Barroso Jr U, Bastos Netto JM, Zerati Filho M, Macedo Jr A, et al. Cross-cultural adaptation of the dysfunctional voiding score symptom (DVSS) questionnaire for Brazilian children. Int Braz J Urol. 2010;36(4):458-63. doi: 10.1590/S1677-55382010000400009

6. Machado VQ, Fonseca EMGO. Disfunção vesical e intestinal em crianças e adolescentes. Brazilian J Health Biomedical Sci. 2016;15(2):146-54. doi: 10.12957/rhupe.2016.28240

7. Martinez AP, Azevedo GR. The Bristol Stool Form Scale: its translation to Portuguese, cultural adaptation and validation. Rev Latino-Am Enferm[Internet]. 2012 [cited 2019 Sep 14];20(3):583-9. Available from: http://www.scielo.br/pdf/rlae/v20n3/a21v20n3.pdf

8. Azevedo RVM, Oliveira EA, Vasconcelos MMA, Castro BAC, Pereira FR, Duarte NFV, et al. Impact of an interdisciplinary approach in children and adolescentes with lower urinary tract dysfunction (LUTD). J Bras Nefrol. 2014;36(4):451-9. doi: 10.5935/0101-2800.20140065

9. Lebl A, Fagundes SN, Koch VHK. Clinical course of a cohort of children with non-neurogenic daytime urinary incontinence symptoms followed at a tertiary center. J Pediatr (Rio J.). 2016;92(2):129-35. doi: 10.1016/j.jped.2015.04.005 
10. Vaz JC. Milbrath VM, Gabatz RIB, Krug FR, Hirschmann B, Oliveira, MM. Care for families of children with chronic disease. Rev Enferm UFPE. 2018;12(5):1397-408. doi: 10.5205/1981-8963-v12i5a230852p1397-1408-2018

11. Oliveira IAMI, Salviano C, Martins G. Children with urinary incontinence: impact on family members coexistence. Rev Enferm UFPE. 2018;12(7):2061-73. doi: 10.5205/1981-8963-v12i7a234837p2061-2073-2018

12. Cederblad M, Nevéus T, Åhman A,Österlund Efraimsson E, Sarkadi A. “Nobody Asked Us if We Needed Help”: Swedish parents experiences of enuresis. J Pediatr Urol. 2014;10:74-9. doi: 10.1016/j.jpurol.2013.06.006

13. Kaugars AS, Silverman A, Kinservik M, Heinze S, Reinemann L, Sander M, et al. Families' perspectives on the effect of constipation and fecal incontinence on quality of life. J Pediatr Gastroenterol Nutr. 2010;51(6):747-52. doi: 10.1097/MPG.0b013e3181 de0651

14. Menezes RP. Enurese noturna monossintomática. J Pediatr. 2001;77(3). doi: 10.1590/S0021-75572001000300005

15. Souza BML, Salviano CF, Martins G. Advanced practice nursing in pediatric urology: experience report in the Federal District. Rev Bras Enferm. 2018;71(1):223-7. doi: 10.1590/0034-7167-2016-0654

16. Fernandez HGC, Moreira MCN, Gomes R. Making decisions on health care for children / adolescents with complex chronic conditions: a review of the literature. Ciênc Saúde Colet. 2019;24(6):2279-2292. doi: 10.1590/1413-81232018246.19202017

17. Benner P. Interpretive phenomenology: embodiment, caring, and ethics in health and illness. Newbury Park (CA): Sage; 1994, 372p.

18. Santos RP, Neves ET, Carnevale F. Qualitative methodologies in health research: interpretive referential of Patricia Benner. Rev Bras Enferm. 2016;69(1):178-82. doi: 10.1590/0034-7167.2016690125i

19. Tong A, Sainsbury P, Craig J. Consolidated criteria for reporting qualitative research (COREQ): a 32-item checklist for interviews and focus groups. Int J Qual Health Care. 2007;19(6):349-57. doi: 10.1093/intqhc/mzm042

20. Pinto JP. Ribeiro CA, Pettengill MM, Balieiro MMFG. Cuidado centrado na família e sua aplicação na enfermagem pediátrica. Rev Bras Enferm. 2010;63(1):132-5. doi: 10.1590/S0034-71672010000100022

21. Figueiredo SH, Lima LA, Batista e Silva DP, Oliveira RMC, Santos MP, Gomes ILV. Importance of health guidance for family members of children with sickle cell disease Rev Bras Enferm. 2018;71(6):2974-82. doi: 10.1590/0034-7167-2017-0806

22. McHugh C, Bailey S, Shilling V, Morris C. Meeting the information needs of families of children with chronic health conditions. Phys Occup Ther Pediatr. 2013;33(3):265-70. doi: 10.3109/01942638.2013.799628

23. Perez J. Early intervention for childhood continence problems. Community Practitioner. 2014;87(7):44-6.

24. Taylor D, Cahill JJ. From stigma to the spotlight: a need for patient-centred incontinence care. Healthc. Manage. Forum. 2018. 31(6):261-264. doi: 10.1177/0840470418798102

25. Veloso LA, Mello MJG, Ribeiro JPM, Barbosa LNF, Silva EJC. Quality of life, cognitive level and school performance in children with functional lower urinary tract dysfunction. J Bras Nefrol. 2016;38(2):234-44. doi:10.5935/0101-2800.20160033

26. Berry AK. Bladder-Bowel Dysfunction in children: consequences, risk factors and recommendations for primary care interventions. Curr Pediatr Rep. 2018;6:220. doi: 10.1007/s40124-018-0178-3

27. Rodrigues B, Pacheco S, Dias M, Cabral J, Luz G, Silva T. Ethical perspective in pediatric nursing care: a view by the nurses. Rev Enferm UERJ [Internet]. 2013[cited 2019 Sep 14];21(6):743-7. Available from: https://www.e-publicacoes.uerj.br/index.php/enfermagemuerj/article/ view/12038/9426

28. Soares AHR, Moreira MCN, Monteiro LMC, Fonseca EMGO. A enurese em crianças e seus significados para suas famílias: abordagem qualitativa sobre uma intervenção profissional em saúde. Rev. Bras. Saúde Mater. Infant. (Online). [Internet]. 2005. 5(3): 301-311. doi: 10.1590/S1519-38292005000300006 Portuguese

29. Valença MP, Albuquerque AFLL, Rocha GMS, Aguiar APD. Cuidados de enfermagem na incontinência urinária: um estudo de revisão integrativa. Estima. 2016;14(1):43-9. doi: 10.5327/Z1806-3144201600010007

30. Duelund-Jakobsen J, Haas S, Buntzen S, Lundby L, Bøje G, Laurberg S. Nurse-led clinics can manage faecal incontinence effectively: results from a tertiary referral centre. Colorectal Dis. 2015;17:710-5. doi:10.1111/codi.12983

31. Wagg A. Improving continence care around the world. Nurs Times [Internet]. 2015 [cited 2019 Sep 14];111(22):22-23. Available from: https:// pubmed.ncbi.nlm.nih.gov/26201156/

32. Hillery S. Developing a new one-stop urology diagnostics service. Braz J Nurs. 2018 [cited 2019 Sep 14];27(18):S22-S25. doi: 10.12968/ bjon.2018.27.18.S22 